\title{
First record of intestinal parasites in a wild population of jaguar in the Brazilian Atlantic Forest
}

\author{
Primeiros registros de parasitos intestinais em uma populaçáo silvestre de \\ onça-pintada na Mata Atlântica Brasileira \\ Ana Carolina Srbek-Araujo ${ }^{1,2 *}$; Juliana Lúcia Costa Santos ${ }^{3}$; Viviane Medeiros de Almeida \\ Marcos Pezzi Guimarães ${ }^{3}$; Adriano Garcia Chiarello ${ }^{4}$
}

\begin{abstract}
${ }^{1}$ Programa de Pós-graduação em Ecologia de Ecossistemas, Universidade Vila Velha - UVV, Vila Velha, ES, Brasil
${ }^{2}$ Programa de Pós-graduação em Ecologia, Conservação e Manejo de Vida Silvestre, Instituto de Ciências Biológicas, Universidade Federal de Minas Gerais - UFMG, Belo Horizonte, MG, Brasil

${ }^{3}$ Laboratório de Helmintologia Veterinária, Departamento de Parasitologia, Instituto de Ciências Biológicas, Universidade Federal de Minas Gerais - UFMG, Belo Horizonte, MG, Brasil

${ }^{4}$ Departamento de Biologia, Faculdade de Filosofia Ciências e Letras de Ribeirão Preto - FFCLRP, Universidade de São Paulo - USP, Ribeirăo Preto, SP, Brasil
\end{abstract}

Received March 11, 2014

Accepted July 25, 2014

\begin{abstract}
Small and isolated wildlife populations may be more susceptible to disease, which makes illness an important issue to investigate regarding the conservation of large carnivores. Here, we present the results of the first investigation of intestinal parasites in one of the last remaining populations of jaguars in the Brazilian Atlantic Forest. We studied parasites from fecal samples using three different techniques for parasitological examination: floatation in saturated sodium chloride solution, sedimentation and formalin-ether centrifugation. Intestinal parasites were detected in $70 \%$ of the analyzed samples, and seven taxa (mean $=3.7 \mathrm{taxa} / \mathrm{sample}$ ) were identified. All the groups of parasites that were identified have been recorded in previous jaguar studies. However, the records of Class Trematoda and nematodes Trichuridae are the first evidence of these groups of worms in free-ranging jaguars in Brazil. Although our results do not provide conclusive evidence on the health of this jaguar population, given its very small size (approximately 20 animals) we stress the need to properly understand the dynamics of disease in this wild population and to evaluate the risk of contracting new diseases from domestic species inhabiting the neighboring areas. These represent imperative actions for the successful conservation of this threatened population of jaguar.
\end{abstract}

Keywords: Panthera onca, parasitology, wildlife, worms.

\section{Resumo}

Populaçốes pequenas e isoladas são mais suscetíveis a doenças, o que torna a investigaçáo de enfermidades uma questâo importante para a conservação de grandes carnívoros. O presente estudo apresenta os resultados da primeira investigação de parasitos intestinais em uma das últimas populaçóes remanescentes de onça-pintada na Mata Atlântica brasileira. Os parasitos foram obtidos a partir de amostras fecais, sendo utilizadas três técnicas para exame parasitológico: flutuação em solução saturada de cloreto de sódio (Método de Willis), sedimentação (Método de HPJ) e centrifugação com formol-éter. Parasitos intestinais foram detectados em $70 \%$ das amostras analisadas, tendo sido identificados sete táxons (média $=3,7$ taxa/amostra). Todos os grupos de parasitos identificados foram mencionados em estudos anteriores realizados com onças-pintadas. Entretanto, os registros de Trematoda e nematoides Trichuridae aqui obtidos representam a primeira evidência desses grupos de vermes em onças-pintadas de vida livre no Brasil. Embora os resultados obtidos não sejam conclusivos quanto à saúde da populaçáo estudada, em virtude do tamanho populacional reduzido (aproximadamente 20 indivíduos), recomenda-se a investigação da dinâmica de doenças, bem como a avaliaçáo do risco de contração de novas doenças a partir do contato com animais domésticos provenientes do entorno da área estudada. Essas investigaçôes são fundamentais para a conservação dessa população ameaçada de onças-pintadas.

Palavras-chave: Panthera onca, parasitologia, vida silvestre, vermes.

*Corresponding author: Ana Carolina Srbek-Araujo, Programa de Pós- 


\section{Introduction}

Diseases are particularly relevant for the conservation of large carnivores because many species or populations of large predators are currently seriously threatened by other factors, such as reduced distribution, habitat loss, overexploitation of prey populations and persecution by man (MURRAY et al., 1999). Taken together, these factors further increase the risk of species loss.

The jaguar (Panthera onca Linnaeus, 1758) is the largest cat in the Americas. Its historical range extended from the southwestern United States to northern Argentina (SEYMOUR, 1989). Currently, the species is considered extinct in part of its original distribution (SANDERSON et al., 2002). In Brazil, the most significant populations are located in the Pantanal and Amazon regions (SILVEIRA; CRAWSHAW Jr., 2008), and the Atlantic Forest represents an area where the species is more threatened (SANDERSON et al., 2002). The current presence of the species has been confirmed in eight regions or locations in the entire biome, and all subpopulations in the Brazilian Atlantic Forest are declining (BEISIEGEL et al., 2012). These subpopulations are restricted to isolated areas and small remnant areas, which is extremely grave considering the ecological and behavioral demands of the species.

Wildlife populations in small areas may be more susceptible to diseases due to higher population densities and increased transmission of infectious diseases among individuals (micro or macroparasites), which also contributes to increased parasite loads due to repeated reinfection (GILBERT, 1994). In this context, diseases can become additional threats to the conservation of wildlife by contributing to the decrease in the viability of populations due to reduced individual longevity (PRIMACK; RODRIGUES, 2001). These issues are more devastating in small, isolated and/or declining populations (MURRAY et al., 1999) and in populations with malnutrition, stress (ULLREY, 1993) and/or high inbreeding rates (O'BRIEN et al., 1985).

This study presents the results of the first efforts to characterize the intestinal parasites in a wild jaguar population in the Atlantic Forest from southeastern Brazil. This population represents the very last population of the species in the state of Espírito Santo and one of the last populations in the entire biome.

\section{Materials and Methods}

\section{Study area}

The study was conducted in the Reserva Natural Vale (RNV, Vale Natural Reserve), which is located $30 \mathrm{~km}$ north of the Doce River, between the municipalities of Linhares and Jaguaré in the state of Espírito Santo, southeastern Brazil (19 $06^{\prime}-19^{\circ} 18^{\prime} \mathrm{S}$ and $\left.39^{\circ} 45^{\prime}-40^{\circ} 19^{\prime} \mathrm{W}\right)$. The RNV is a private protected area $(22,711$ ha) and it is adjacent to the Reserva Biológica de Sooretama (RBS, Sooretama Biological Reserve $=27,859$ ha). Together, these reserves form a continuous block of native vegetation (Linhares/ Sooretama block) that is intercepted by the BR-101 highway and represent $10 \%$ of the remaining area of native forest in the state (SOSMA; INPE, 2011).

\section{Sample collection and laboratory procedures}

The parasitological tests were performed using fecal samples collected in the RNV between November 2006 and October 2007. The samples were collected monthly along internal unpaved roads located within the Reserve. These roads were surveyed by two observers on bicycles. A total of $547 \mathrm{~km}$ of internal roads were covered in the RNV during the sampling period.

Only fresh fecal samples (damp and shiny surface; strong odor) were collected for parasitological examinations. This type of fecal sample is more likely to contain parts of parasites that are still intact. We collected one slice of the internal portion of each sample, placed it in an 80-ml plastic bag and preserved the sample in MIF solution (Merthiolate-Iodine-Formaldehyde) for better fixation of the cysts and oocysts of protozoans and the eggs and larvae of helminthes, as well as adult worms. We stored the remainder of the feces in plastic bags, and they were maintained frozen in the RNV field laboratory until further analysis. The samples were later sent to the Laboratory of Veterinary Helminthology at Universidade Federal de Minas Gerais (UFMG) for analysis.

We collected all fresh fecal samples of felids encountered in the field regardless of the sample size, as there is considerable overlap in feces morphology and dimensions between jaguars and other cat species present in the RNV, particularly the puma (Puma concolor Linnaeus, 1771) and ocelot (Leopardus pardalis Linnaeus, 1758) (FARRELL et al., 2000; HAAG et al., 2009; MIOTTO et al., 2007). We identified the cat species by searching for guard hairs (hair ingested by specimens during self-cleaning and eliminated in the feces) and comparing them with a reference collection (futher details can be found in DEL DUQUE Jr., 2012). We also used genetic analysis to assist in the identification of cat species (fecal DNA extraction) (details of the methodology and results can be found in HAAG et al., 2009 and SRBEK-ARAUJO, 2013).

We performed macroscopic examination of the samples, followed by detailed analysis of the fractions selected with the stereomicroscope, to investigate the presence of adult parasites. We used the following methods for finding cysts, oocysts, eggs and the larvae of parasites in the samples: floatation in saturated sodium chloride solution (WILLIS, 1921), sedimentation (HOFFMAN et al., 1934) and formalin-ether centrifugation (RITCHIE, 1948). We identified the parasitic forms by light microscopy. We used different methods to optimize data collection, as there is no single method capable of diagnosing all parasitic forms concomitantly (SOUZA; AMOR, 2010).

The identification of parasites followed Soulsby (1968), Skryabin (1969) and Yamaguti (1961, 1963).

\section{Results}

We sent 10 fresh jaguar fecal samples collected in the RNV to the laboratory for parasitological examinations. In total, $70 \%$ of the samples were positive for the presence of intestinal parasites. Seven taxa were identified from oocysts or eggs: Phylum Apicomplexa, Phylum Acanthocephala, Order Pseudophyllidea (Cestoda), Class Trematoda, Family Ancylostomatidae (Nematoda), Family Ascarididae (Nematoda) and Family Trichuridae (Nematoda) (Table 1; Figure 1). Two different forms of eggs of Ascarididae were 
Table 1. Intestinal parasites identified in jaguar fecal samples collected in the Reserva Natural Vale (Linhares/ES). The parasitic forms detected in the samples and the number of positive samples of each parasite (\# samples) are also included.

\begin{tabular}{ccccccc}
\hline Phylum & Class & Order & Superfamily & Family & Parasitic Form & Parasite (\# samples) \\
\hline Apicomplexa & & & & oocyst & Apicomplexa (2) \\
Acanthocephala & & & & & egg & Acanthocephala (4) \\
Platyhelminthes & Cestoda & Pseudophyllidea & & & egg & Pseudophyllidea (5) \\
Platyhelminthes & Trematoda & & & & egg & Trematoda (3) \\
Nematoda & Chromadorea & Strongylida & Ancylostomatoidea & Ancylostomatidae & egg & Ancylostomatidae (5) \\
Nematoda & Chromadorea & Ascaridida & Ascaridoidea & Ascarididae & egg & Ascarididae 1 (2) \\
Nematoda & Chromadorea & Ascaridida & Ascaridoidea & Ascarididae & egg & Ascarididae 2 (3) \\
Nematoda & Chromadorea & Ascaridida & Ascaridoidea & Ascarididae & adult & Toxocara sp. (1) \\
Nematoda & Enoplea & Enoplida & Trichinelloidea & Trichuridae & egg & Trichuridae (1) \\
\hline
\end{tabular}
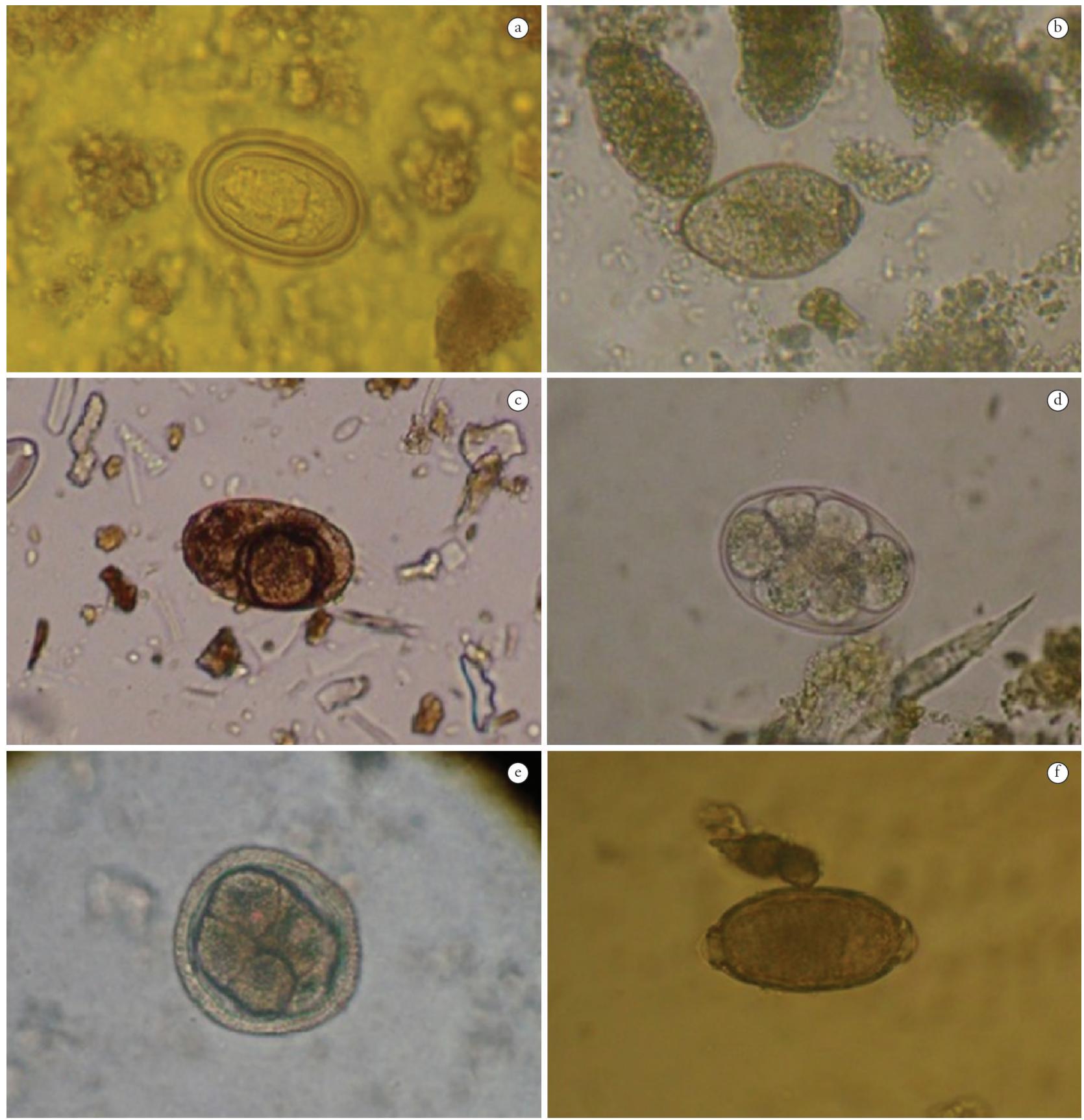

Figure 1. Eggs of intestinal parasites identified in jaguar fecal samples collected in the Reserva Natural Vale (Linhares/ES): a. Acanthocephala; b. Pseudophyllidea; c. Trematoda; d. Ancylostomatidae; e. Ascarididae; f. Trichuridae. 
found. We detected adult parasites in only one sample, represented by the nematode Toxocara sp. (Family Ascarididae) (Table 1).

We detected between two and six different taxa of parasites per positive sample (mean = 3.7 taxa). The cestodes Pseudophyllidea and the nematodes Ancylostomatidae were the most common groups of parasites (detected in five samples), followed by Acanthocephala (recorded in four samples). We recorded the nematodes Trichuridae in only one fecal sample.

According to the data obtained from the genetic analyses (see SRBEK-ARAUJO, 2013 for details), three fecal samples collected in different months belonged to the same individual jaguar. We identified four taxa of parasites in the first fecal sample (November 2006: Phylum Apicomplexa, cestodes Pseudophyllidea, Class Trematoda and nematodes Ancylostomatidae); no intestinal parasites in the second sample (April 2007); and only two parasites in the third sample (July 2007: the cestodes Pseudophyllidea and nematodes Ancylostomatidae). Considering these three samples, the total number of taxa identified for this individual jaguar was equal to that identified in the first sample $(n=4)$.

\section{Discussion}

Studies related to the investigation of intestinal parasites in wild jaguars are scarce, and most of the available information for the species comes from individuals housed in captivity (e.g., OTTO, 1974; PATTON et al., 1986; MÜLLER et al., 2005; CASTRO; ALBUQUERQUE, 2008; FURTADO; FILONI, 2008; VIEIRA et al., 2008; BRANDÁO et al., 2009). Nevertheless, the data available in the scientific literature represent a total of five Phyla and 15 Families of jaguar intestinal parasites. All the taxa identified in the jaguar population in the RNV have been recorded in previous studies. However, the records of the Class Trematoda and the nematodes Trichuridae obtained in the present study are the first records of these groups in free-ranging jaguars in Brazil. The nematodes Trichuridae have been recorded in free-ranging puma and oncilla (Leopardus tigrinus Schreber, 1775) (VIEIRA et al., 2008), and the Class Trematoda has been previously recorded only in the jaguarundi (Puma yagouaroundi É. Geoffroy, 1803) (SIMÓES-BARBOSA; PONTUAL, 1949) in studies with wild cats in Brazi. These three species of wild cats also inhabit the RNV.

The average number of parasite taxa/sample in the RNV is higher than in a previous study of wild cat species $(n=2)$ in Belize (PATTON et al., 1986). However, the maximum number of taxa/sample was higher in the study of Patton et al. (1986) (up to eight taxa).

The variation in the number of parasite taxa identified in different fecal samples from the same individual, including a sample considered negative for the presence of parasites (no parasites found), indicate that the non-detection of parasites in fecal samples may actually represent false-negative results. Regarding these results, we agree with Souza and Amor (2010), who stated that when only one sample is analyzed and the result is negative, it should not be evaluated as conclusive. According to these authors, the production of eggs, larvae, cysts and oocysts is not uniform throughout the day or during the life cycle of the parasite (SOUZA; AMOR, 2010). When considering the lack of evidence of parasites in general or for a particular taxon of parasite, we further suggest that false-negative results may be related to the heterogeneous distribution of parasitic forms in a given fecal sample. This may lead to biased results when only one portion of the feces is collected for parasitological examinations.

Intestinal parasites in general, particularly the helminths, have not been identified as a cause of death in wild animals; however, they are associated with changes in behavior, reproduction and assimilation of nutrients, which can result in individuals being more vulnerable to other environment pressures (ANDERSON, 1976). However, the age of the infected animal and the intensity of the infection can influence the severity of the intestinal parasitic infections. The parasites can cause, for example, mechanical obstruction of the intestine due to the existence of a large number of adult parasites and severe anemia due to the extraction of nutrients, ultimately reducing the nutritional status of the host (BOWMAN, 2010). However, such manifestations are observed only in prolonged and massive parasitism cases (BOWMAN, 2010).

Beyond the susceptibility to a wide variety of parasites (viruses, bacteria, protozoa and helminths, among other groups), carnivores are vulnerable to pathogens that are easily transmitted from domestic species (MURRAY et al., 1999). The contact between wild species and domestic dogs (Canis lupus familiaris Linnaeus, 1758), for example, which has been recorded in different regions of the Atlantic Forest (GALETTI; SAZIMA, 2006; SRBEK-ARAUJO; CHIARELLO, 2008; PASCHOAL et al., 2012), may promote disease transmission among these groups. And the transmission of diseases is identified as one of the most serious consequences of the contact between native and exotic animals (HAASS et al., 1996; ROELKE-PARKER et al., 1996; CARPENTER et al., 1998; CLEAVELAND et al., 2000; BUTLER et al., 2004). The RNV has an irregular shape (high extension of edges) and is surrounded by areas consisting mainly of pasture and crops (JESUS; ROLIM, 2005). In this scenario, the possibility of contact between jaguars and domestic dogs, culminating with the introduction of new parasites in the wild population, is a real threat for the conservation of this large cat. Indeed, the presence of domestic dogs has been recorded in the RNV through direct sightings, records of vocalizations and camera traps (SRBEK-ARAUJO; CHIARELLO, 2013). This situation is further aggravated by the extremely small size and isolation of this jaguar population in the Linhares/Sooretama block, with estimations of only approximately 20 animals (SRBEK-ARAUJO, 2013).

Although information on the known impacts of disease on wild populations of jaguars is limited (FURTADO; FILONI, 2008), the effects may become more severe in small and isolated populations (MURRAY et al., 1999) and in populations exposed to inbreeding depression (O'BRIEN et al., 1985). Unfortunately, these conditions are shared by all surviving populations of jaguars across the Atlantic Forest biome. Thus, it is necessary to conduct investigations and monitoring to properly understand the dynamics of disease in wild populations of jaguars (FURTADO; FILONI, 2008). The identification of parasites present in the remaining populations and the evaluation of the risk of contracting other diseases, particularly from domestic species inhabiting the neighboring areas, are of particular importance. 
It is relevant to highlight that diseases transmitted between wildlife and domestic animals are often bi-directional. They can be fatal to both groups with the potential for transmission to humans, therefore favoring the emergence of new zoonoses (BENGIS et al., 2002). For this reason, the avoidance and prevention of contact between wild and domestic animals not only contribute to the conservation of threatened native species but also represent a preventive action benefiting public health.

\section{Acknowledgments}

The data in this paper are part of the research project "Population Size, Density and Habitat Use by Jaguar (Panthera onca, Carnivora, Felidae) in Reserva Natural Vale, Linhares, Espírito Santo/ Brazil". We thank Vale S.A./Instituto Ambiental Vale for their financial support. Braz Guerini and Jesuíno Barreto for their help with the field activities. A. G. Chiarello is sponsored by $\mathrm{CNPq}$ (303273/2008-9 and 306848/2011-2).

\section{References}

Anderson RC. Helminths. In: Page LA. III International Wildlife Disease Conference. New York: Plenum; 1976. p. 35-43. PMid:1047575. http:// dx.doi.org/10.1007/978-1-4757-1656-6_5

Beisiegel BM, Sana DA, Moraes EA Jr. The jaguar in the Atlantic Forest. Cat News Special Issue 2012; (7): 14-18.

Bengis RG, Kock RA, Fischer J. Infectious animal diseases: the wildlife/ livestock interface. Rev Sci Tech 2002; 21(1): 53-65. PMid:11974630.

Bowman DD. Georgis: parasitologia veterinária. São Paulo: Elsevier; 2010.

Brandão ML, Chame M, Cordeiro JLP, Chaves SAM. Diversidade de helmintos intestinais em mamíferos silvestres e domésticos na Caatinga do Parque Nacional Serra da Capivara, Sudeste do Piauí, Brasil. Rev Bras Parasitol Vet 2009; 18(S1): 19-28. PMid:20040186. http://dx.doi. org/10.4322/rbpv.018e1004

Butler JRA, Du Toit JT, Bingham J. Free-ranging domestic dogs (Canis familiaris) as predators and prey in rural Zimbabwe: threats of competition and disease to large wild carnivores. Biol Conserv 2004; 115(3): 369-378. http://dx.doi.org/10.1016/S0006-3207(03)00152-6

Carpenter MA, Appel MJG, Roelke PME, Munson L, Hofer H, East $\mathrm{M}$, et al. Genetic characterization of canine distemper virus in Serengeti carnivores. Vet Immunol Immunopathol 1998; 65(2-4): 259-266. http:// dx.doi.org/10.1016/S0165-2427(98)00159-7

Castro LS, Albuquerque GR. Ocorrência de Platynosomum illiciens em felinos selvagens mantidos em cativeiro no estado da Bahia, Brasil. Rev Bras Parasitol Vet 2008; 17(4): 239-241. PMid:19265585.

Cleaveland S, Appel MGJ, Chalmers WSK, Chillingworth C, Kaare M, Dye C. Serological and demographic evidence for domestic dogs as a source of canine distemper virus infection for Serengeti wildlife. Vet Microbiol 2000; 72(3-4): 217-227. http://dx.doi.org/10.1016/S03781135(99)00207-2

Del Duque HJ Jr. A dieta da onça-pintada em uma das últimas populaçóes deste felino na Mata Atlântica: a Reserva Natural Vale, Linhares (ES), sudeste do Brasil [Dissertação]. Belo Horizonte: Pontifícia Universidade Católica de Minas Gerais; 2012.
Farrell LE, Roman J, Sunquist ME. Dietary separation of sympatric carnivores identified by molecular analysis of scats. Mol Ecol 2000; 9(10): 1583-1590. PMid:11050553. http://dx.doi.org/10.1046/j.1365294x.2000.01037.x

Fundação SOS Mata Atlântica - SOSMA. Instituto Nacional de Pesquisas Espaciais - INPE. Atlas dos Remanescentes Florestais da Mata Atlântica: período 2008-2010 [online]. 2011 [cited 2012 Aug 7]. Available from: mapas.sosma.org.br/site_media/download/atlas_2008-10_relatorio $\% 20$ final_versao2_julho2011.pdf.

Furtado MM, Filoni C. Diseases and their role for jaguar conservation. Cat News Special Issue 2008; 4: 35-40.

Galetti M, Sazima I. Impacto de cães ferais em um fragmento urbano de Floresta Atlântica no sudeste do Brasil. Nat Conserv 2006; 4(1): 58-63.

Gilbert KA. Parasitic infection in red howling monkeys in forest fragments. Neotrop Primates 1994; 2(2): 10-12.

Haag T, Santos AS, Angelo C, Srbek-Araujo AC, Sana DA, Morato RG, et al. Development and testing of an optimized method for DNAbased identification of jaguar (Panthera onca) and puma (Puma concolor) faecal samples for use in ecological and genetic studies. Genetica 2009; 136(3): 505-512. PMid:19137401. http://dx.doi.org/10.1007/s10709008-9347-6

Haass L, Hofer H, East M, Wohlsein P, Liess B, Barrett T. Canine distemper virus infection in Serengeti spotted hyenas. Vet Microbiol 1996; 49(1-2): 147-152. http://dx.doi.org/10.1016/0378-1135(95)00180-8

Hoffman WA, Pons JA, Janer JL. The sedimentation-concentration method in schistosomiasis mansoni. P RJ Public Health Trop Med 1934; 9(3): 281-298.

Jesus RM, Rolim SG. Fitossociologia da Mata Atlântica de Tabuleiro. Viçosa: Sociedade de Investigaçáo Florestal; 2005. Boletim Técnico SIF. vol. 19. p. 1-149.

Miotto RA, Rodrigues FP, Ciocheti G, Galetti PM Jr. Determination of the minimum population size of pumas (Puma concolor) through fecal DNA analysis in two protected cerrado areas in the Brazilian southeast. Biotropica 2007; 39(5): 647-654. http://dx.doi.org/10.1111/j.17447429.2007.00315.x

Müller GCK, Greinert JÁ, Silva HH Fo. Freqüência de parasitas intestinais em felinos mantidos em zoológicos. Arq Bras Med Vet Zootec 2005; 57(4): 559-561. http://dx.doi.org/10.1590/S0102-09352005000400021

Murray DL, Kapke CA, Evermann JF, Fuller TK. Infectious disease and the conservation of free-ranging large carnivores. Anim Conserv 1999; 2(4): 241-254. http://dx.doi.org/10.1111/j.1469-1795.1999.tb00070.x

O’Brien SJ, Roelke ME, Marker L, Newman A, Winkler CA, Meltzer $\mathrm{D}$, et al. Genetic basis for species vulnerability in the cheetah. Science 1985; 227(4693): 1428-1434. PMid:2983425. http://dx.doi. org/10.1126/science.2983425

Otto GF. Occurrence of the heartworm in unusual locations and in unusual hosts. In: American Heartworm Society. Proceedings of the Heartworm Symposium. Washington: American Heartworm Society Press; 1974. p. 6-13.

Paschoal AMO, Massara RL, Santos JL, Chiarello AG. Is the domestic dog becoming an abundant species in the Atlantic forest? A study case in southeastern Brazil. Mammalia 2012; 76(1): 67-76. http://dx.doi. org/10.1515/mammalia-2012-0501

Patton S, Rabinowitz A, Randolph S, Johnson SS. A coprological survey of parasites of wild neotropical felidae. J Parasitol 1986; 72(4): 517-520. PMid:3783346. http://dx.doi.org/10.2307/3281500 
Primack RB, Rodrigues E. Biologia da conservação. Londrina: Midiograf; 2001.

Ritchie LS. An ether sedimentation technique for routine stool examinations. Bull U S Army Med Dep 1948; 8(4): 326.

Roelke-Parker ME, Munson L, Packer C, Kock R, Cleaveland S, Carpenter M, et al. A canine distemper virus epidemic in Serengeti lions (Panthera leo). Nature 1996; 379(6564): 441-445. PMid:8559247. http:// dx.doi.org/10.1038/379441a0

Sanderson E, Redford KH, Chetkiewicz C, Medellin RA, Rabinowitz A, Robinson JG, et al. Planning to save a species: the jaguar as a model. Conserv Biol 2002; 16(1): 58-72. http://dx.doi.org/10.1046/j.15231739.2002.00352.x

Seymour KL. Panthera onca. Mamm Species 1989; (340): 1-9. http:// dx.doi.org/10.2307/3504096

Silveira L, Crawshaw P Jr. Panthera onca Linnaeus, 1758. In: Machado ABM, Drummond GM, Paglia AP. Livro Vermelho da fauna brasileira ameaçada de extinçâo. Brasília: Ministério do Meio Ambiente; Belo Horizonte: Fundaçáo Biodiversitas; 2008. p. 793794. PMid:18237722.

Simões-Barbosa FA, Pontual C. A new host for Platynosomum fastosum Kossack, 1910 (Trematoda: Dicrocoeliidae). J Parasitol 1949; 35(5): 546-547. http://dx.doi.org/10.2307/3273665

Skryabin KI. Key to parasitic nematodes. Jerusalem: IPST Press Binding; 1969. vol. 1. Spirurata and filariata.

Soulsby EJL. Helminths, Arthropods \& Protozoa of domesticated animals. London: Baillière, Tindall and Cassell; 1968.
Souza RF, Amor ALM. Controle de qualidade de técnicas realizadas nos laboratórios de parasitologia da Secretaria Municipal de Saúde do Município de Salvador, Bahia. Rev Bras Anal Clin 2010; 42(2): 101-106.

Srbek-Araujo AC. Conservação da Onça-pintada (Panthera onca Linnaeus, 1758) na Mata Atlântica de Tabuleiro do Espírito Santo [Tese]. Belo Horizonte: Universidade Federal de Minas Gerais; 2013. PMid:24264975.

Srbek-Araujo AC, Chiarello AG. Domestic dogs in Atlantic Forest preserves of south-eastern Brazil: a camera-trapping study on patterns of entrance and site occupancy rates. Braz J Biol 2008; 68(4): 771-779. http://dx.doi.org/10.1590/S1519-69842008000400011

Srbek-Araujo AC, Chiarello AG. Influence of camera-trap sampling design on mammal species capture rates and community structures in southeastern Brazil. Biota Neotrop 2013; 13(2): 51-62. http://dx.doi. org/10.1590/S1676-06032013000200005

Ullrey DE. Nutrition and predisposition to infectious disease. JZoo Wildl Med 1993; 24(3): 304-314.

Vieira FM, Luque JL, Muniz-Pereira LSC. Checklist of helminth parasites in wild carnivore mammals from Brazil. Zootaxa 2008; 1721: 1-23.

Willis HH. A simple levitation method for the detection of hookworm ova. Med J Australia 1921; 11: 375-376.

Yamaguti S. Systema Helminthum: the nematodes of vertebrates. New York: Interscience; 1961

Yamaguti S. Systema Helminthum: Acanthocephala. New York: Interscience; 1963. PMid:14047863. 